\title{
ASPEK HUKUM PELAKSANAAN VAKSINASI \\ MENINGITIS MENINGOKOKUS UNTUK JAMAAH UMRAH \\ DI KANTOR KESEHATAN PELABUHAN KELAS II CILACAP \\ Oleh : Wawan Sulistiyadi ${ }^{1}$
}

\begin{abstract}
ABTRACT
The State insists on the obligation of the State over the health of its citizens rights as mentioned in Article 34 paragraph (3) of the 1945 CONSTITUTION States that health is a constitutional right of every citizen and the responsibility for the State to providing health services.

Juridical analysis of the approach in this paper is the approach by analyzing about communication as well as harmonization of the law in the perspective of legal certainty, the protection of the law, awareness of the law and good governance.

Neisseria meningitidis meningitis vaccination services for umrah pilgrims held in CTF class II Cilacap given to communities who will travel to the country's endemic meningitis vaccinations given at least thirty days prior to departure based on the FMD No. 13 year 2016 or at least 10 days before the departure in accordance with guidelines Immunology in vaccination.

Key Words: vaccination, the health, umrah pilgrims
\end{abstract}

\begin{abstract}
ABSTRAK
Negara menegaskan tentang kewajiban negara atas hak kesehatan warga negaranya seperti yang disebutkan di dalam Pasal 34 ayat (3) UUD 1945 yang menyebutkan bahwa kesehatan merupakan hak konstitusional setiap warga negara dan tanggung jawab bagi negara untuk menyediakan pelayanan kesehatan.

Pendekatan analisis yuridis dalam tulisan ini adalah pendekatan dengan menganalisis mengenai komunikasi serta harmonisasi hukum dalam perspektif kepastian hukum, perlindungan hukum, kesadaran hukum serta good governance.

Pelayanan vaksinasi meningitis meningokokus bagi jamaah umrah diselenggarakan di KKP Kelas II Cilacap diberikan kepada masyarakat yang akan melakukan perjalanan ke negara endemis vaksinasi meningitis diberikan minimal tiga puluh hari sebelum keberangkatan berdasarkan PMK No. 13 tahun 2016 atau minimal 10 hari sebelum keberangkatan sesuai dengan panduan imunologi dalam vaksinasi.

Kata Kunci: vaksinasi, kesehatan, jamaah umrah
\end{abstract}

\footnotetext{
${ }^{1}$ ASN Kantor Pelabuhan Kelas II Cilacap
} 


\section{A. Pendahuluan}

Kesehatan merupakan hak asasi manusia dan salah satu unsur kesejahteraan yang harus diwujudkan sesuai dengan cita-cita bangsa Indonesia. Undang-Undang Dasar Negara Republik Indonesia Tahun 1945 (UUD 1945) mengakui dan melindungi kesehatan sebagai hak asasi manusia (HAM). Pengakuan ini tertuang di dalam Pasal $28 \mathrm{H}$ ayat (1) yang berbunyi:

Setiap orang berhak hidup sejahtera lahir dan batin, bertempat tinggal dan mendapatkan lingkungan hidup yang baik dan sehat serta berhak memperoleh pelayanan kesehatan.

Negara menegaskan tentang kewajiban negara atas hak kesehatan warga negaranya seperti yang disebutkan di dalam Pasal 34 ayat (3) UUD 1945 yang menyebutkan bahwa kesehatan merupakan hak konstitusional setiap warga negara dan tanggung jawab bagi negara untuk menyediakan pelayanan kesehatan.

Pembangunan sektor kesehatan di Indonesia masuk di dalam bagian dari Rencana Pembangunan Jangka Panjang Nasional (RPJPN) periode 2005-2025 yang tertuang di dalam Rencana Pembangunan Jangka Panjang Bidang Kesehatan (RPJP-
K). Rencana Pembangunan Jangka Panjang Bidang Kesehatan (RPJP-K) adalah rencana pembangunan nasional di bidang kesehatan, yang merupakan penjabaran dari RPJPN Tahun 2005-2025, dalam bentuk dasar, visi, misi, arah dan kebutuhan sumber daya pembangunan nasional di bidang kesehatan untuk masa 20 tahun ke depan, yang mencakup kurun waktu sejak tahun 2005 sampai dengan tahun 2025.

Pembangunan kesehatan adalah upaya yang dilaksanakan oleh semua komponen bangsa Indonesia yang bertujuan untuk meningkatkan kesadaran, kemauan dan kemampuan hidup sehat bagi setiap orang agar terwujud derajat kesehatan masyarakat yang setinggitingginya, sebagai investasi bagi pembangunan sumber daya manusia yang produktif secara sosial dan ekonomis. Pembangunan kesehatan di Indonesia secara umum memiliki tujuan tercapainya derajad kesehatan individu, keluarga dan masyarakat yang setinggi-tingginya.

Peraturan Presiden Nomor 72 Tahun 2012 (PP Nomor 72 Tahun 2012) Tentang Sistem Kesehatan Nasional menyebutkan bahwa Sistem Kesehatan Nasional yang selanjutnya disingkat SKN adalah pengelolaan kesehatan yang diselenggarakan oleh semua komponen bangsa Indonesia secara 
terpadu dan saling mendukung guna menjamin tercapainya derajad kesehatan masyarakat yang setinggitingginya. Sistem Kesehatan Nasional diselenggarakan melalui pengelolaan administrasi kesehatan, informasi kesehatan, sumber daya kesehatan, upaya kesehatan, pembiayaan kesehatan, perta serta dan pemberdayaan masyarakat, ilmu pengetahuan dan teknologi di bidang kesehatan serta pengaturan hukum kesehatan secara terpadu dan saling mendukung guna menjamin tercapainya derajat kesehatan yang setinggi-tingginya.

Perkembangan dan masalah di dalam Sistem Kesehatan Nasional salah salah satunya di dalam subsitem manajemen, informasi dan regulasi kesehatan.. Regulasi kesehatan telah banyak dikeluarkan oleh pemerintah akan tetapi belum tertata secara sistematis dan harmonis serta belum mendukung pembangunan kesehatan secara utuh, peraturan perundanganundangan bidang kesehatan pada saat ini belum cukup, baik jumlah, jenis maupun efektifitasnya.

Perangkat regulasi yang terkait dengan kesehatan masih belum memadai, kemampuan pimpinan tenaga kesehatan dan profesi dalam pemahaman etikolegal dan

2 Lampiran Peraturan Presiden Nomor 72 Tahun 2012, hal. 13 pembuatan regulasi kesehatan spesifik serta kesadaran hukum masyarakat masih rendah dan masih lemahnya penegakan hukum menyebabkan berbagai hambatan dalam penyelenggaraan pembangunan kesehatan. Kondisi ini juga memberikan gambaran bahwa pemerintah belum sepenuhnya dapat menyelenggarakan pembangunan kesehatan yang efektif, efisien, dan bermutu sesuai dengan prinsipprinsip tata pemerintahan yang baik (good governance).

Penataan bidang kesehatan juga tidak terlepas dari keterkaitan dengan penataan di bidang lain, dimana salah satunya adalah bidang keagamaan. Indonesia yang mayoritas masyarakat beragama Islam setiap tahun memiliki rutinitas atau gelaran ibadah akbar yang tidak bisa lepas dari pelayanan dan regulasi kesehatan nasional yaitu ibadah haji dan ibadah umrah, terlebih ibadah haji merupakan satu dari lima rukun Islam. Selain ibadah haji, ibadah umrah intensitasnya semakin tahun semakin meningkat. Minat masyarakat untuk melaksanakan ibadah umrah terus menunjukkan peningkatan yang signifikan seiring dengan semakin panjangnya antrian jamaah haji sementara keinginan masyarakat untuk beribadah ke tanah suci cukup besar. Jumlah jamaah umrah 
Indonesia dalam satu tahun bisa melebihi jumlah jamaah haji di tahun yang sama.

Arab Saudi sebagai tuan rumah bagi jamaah umrah telah mewajibkan setiap jamaah baik haji maupun umrah untuk melakukan vaksinasi meningitis meningokokus sebelum memasuki Arab Saudi. Nota Diplomatik Kedutaan Besar King Saudi Arabia (KSA) di Indonesia nomor 588/PK/VI/06/61 tahun 2006 tentang vaksinasi meningitis meningokokus merupakan syarat untuk mendapatkan visa. Penyakit meningitis meningokokus sendiri merupakan penyakit peradangan pada selaput pembungkus otak yang disebabkan oleh bakteri Neisseria Meningitidis yang masuk dalam jenis penyakit menular yang memiliki potensi penularan dari manusia ke manusia.

Pemerintah Indonesia melalui Kementerian Kesehatan Republik Indonesia mengatur pelayanan vaksinasi meningitis meningokokus pada jamaah umrah menjadi kewenangan Kantor Kesehatan Pelabuhan sesuai Peraturan Menteri Kesehatan Nomor 58 Tahun 2013 tentang Pemberian Sertifikat Vaksinasi Internasional (PMK No. 58 Tahun 2013) yang telah diperbaharui dengan PMK No. 13 Tahun 2016 Tentang Pemberian Sertifikat Vaksinasi Internasional. Vaksinasi meningitis pada dasarnya belum menjadi ketetapan dari pemerintah Indonesia karena ini masih menjadi tindak lanjut dari ketetapan pemerintah Arab Saudi walaupun pada Keputusan Menteri Kesehatan Nomor 442 Tahun 2009 Tentang Pedoman Penyelenggaraan Kesehatan Haji Indonesia menyebutkan bahwa jamaah haji dan petugas haji wajib melakukan vaksinasi meningitis. Sementara terkait dengan ibadah umrah, aturan vaksinasi meningitis disebutkan di dalam Peraturan Menteri Kesehatan Nomor 58 Tahun 2013 Tentang Sertifikat Vaksinasi Internasional yang telah digantikan dengan PMK No. 13 Tahun 2016.

Pelayanan vaksinasi meningitis meningokokus merupakan bentuk upaya kesehatan yang terdiri atas fasilitas pelayanan kesehatan atau tempatnya beserta dengan tenaga kesehatan (sumber daya manusia) yang terlibat di dalamnya yang tentu sangat berkaitan dengan standar pelayanan. Vaksinasi yang menjadi kewenangan dan kompetensi dokter tentu memberikan gambaran bahwa pelayanan vaksinasi ini merupakan bentuk praktik kedokteran. Pelayanan vaksinasi ini sebagaimana telah disebutkan, melibatkan pula adanya tempat berupa fasilitas pelayanan kesehatan dan tenaga kesehatan selain dokter. 
Tenaga kesehatan yang terlibat dalam pelayanan vaksinasi meningitis meningokokus tersebut sudah tentu wajib melaksanakan standar pelayanan, standar profesi serta standar prosedur operasional yang telah ada dan tidak terlepas pula dari fasilitas pelayanan kesehatan yang ada yaitu Kantor Kesehatan Pelabuhan juga wajib memenuhi peraturan yang telah ada. Berdasarkan informasi dari Yayasan Pemberdayaan Konsumen Kesehatan Indonesia (YPKKI), masih banyak pelayanan kesehatan di Indonesia yang belum memenuhi standar regulasi kesehatan baik itu terkait standar pelayanan, standar operasional prosedur serta standar profesi tak terkecuali pada pelayanan vaksinasi meningitis meningokokus di Kantor Kesehatan Pelabuhan. Informasi informal yang peneliti dapat menyatakan bahwa masih banyak tenaga kesehatan di Kantor Kesehatan Pelabuhan yang belum memiliki Surat ljin Praktik dalam kegiatannya sebagai seorang tenaga kesehatan profesional. Hal ini tentu bertolak belakang dengan kewajiban pemerintah dalam penjaminan dan pengawasan mutu pelayanan kesehatan yang didukung dengan standar pelayanan serta komitmen dalam tata pemerintahan yang baik (Good Governance). Pelayanan vaksinasi meningitis meningokokus di
Kantor Kesehatan Pelabuhan dalam hal ini KKP Kelas II Cilacap menurut peneliti, tergolong pelayanan kesehatan primer atau tingkat pertama. Fasilitas pelayanan kesehatan tingkat pertama adalah fasilitas pelayanan kesehatan yang memberikan pelayanan kesehatan dasar. Hal ini perlu dikaji lebih lanjut karena sampai saat ini belum ada keterangan yang baku tentang bentuk fasilitas pelayanan kesehatan di KKP itu sendiri. Pada bagian lain, terhadap fasilitas kesehatan tingkat pertama atau primer dalam hal ini pelayanan kesehatan masyarakat primer telah ada ketentuan yang lebih jelas yaitu terhadap Puskemas dan Klinik.

Berdasarkan uraian di atas, peneliti tertarik untuk melakukan penelitian aspek hukum dalam pelaksanaan pelayanan vaksinasi meningitis di Kantor Kesehatan Pelabuhan dalam hal ini pada Kantor Kesehatan Pelabuhan Kelas II Cilacap. Dasar hukum atau legal standing pelaksanaan vaksinasi meningitis meningokokus bagi jamaah umrah di Kantor Kesehatan Pelabuhan adalah PMK No. 58 Tahun 2013 yang telah diganti dengan PMK No. 13 Tahun 2016 sementara vaksinasi menjadi bagian dari tindakan medis yang tidak bisa lepas dari standar pelayanan dimana diatur dalam peraturan-peraturan 
selain PMK No. 13 Tahun 2016. Di sisi lain, komunikasi dan harmonisasi hukum masih menjadi permasalahan di dalam regulasi kesehatan di Indonesia. Hal ini menjadi tantangan bagi pemerintah dalam mewujudkan sistem kesehatan nasional yang memiliki kepastian hukum, perlindungan hukum, kesadaran hukum serta perwujudan dalam good governance.

\section{B. Metodologi Penelitian}

Metode pendekatan yang digunakan dalam penelitian ini adalah yuridis sosiologis (sosial legal approach), dimaksudkan sebagai pemaparan dan pengkajian hubungan aspek hukum dengan aspek non hukum dalam bekerjanya hukum di dalam kenyataan. Pendekatan analisis yuridis dalam tulisan ini adalah pendekatan dengan menganalisis mengenai komunikasi serta harmonisasi hukum dalam perspektif kepastian hukum, perlindungan hukum, kesadaran hukum serta good governance.

Peneliti dalam penelitian ini, fokus pada pelaksanaan penerapan hukum yang berkaitan dengan vaksinasi dimana merupakan bentuk upaya kesehatan yang memiliki peraturan-peraturan serta standar pelayanan. Diharapkan dari penelitian ini, Peneliti memperoleh kejelasan mengenai aspek hukum kesehatan dalam pelayanan vaksinasi meningitis meningokokus di Kantor Kesehatan Pelabuhan Cilacap.

\section{HASIL DAN PEMBAHASAN}

1. Pelaksanaan

Vaksinasi Meningitis Meningokokus Bagi Jamaah Umrah di Kantor Kesehatan Pelabuhan Kelas II Cilacap

Pelayanan vaksinasi meningitis meningokokus bagi jamaah umrah diselenggarakan di KKP Kelas II Cilacap diberikan kepada masyarakat yang akan melakukan perjalanan ke negara endemis vaksinasi meningitis diberikan minimal tiga puluh hari sebelum keberangkatan berdasarkan PMK No. 13 tahun 2016 atau minimal 10 hari sebelum keberangkatan sesuai dengan panduan imunologi dalam vaksinasi. Pelaksanan vaksinasi meningitis meningokokus bagi jamaah umrah di KKP Cilacap diatur dalam Peraturan Menteri Kesehatan Nomor 58 Tahun 2013 Tentang Sertifikat Vaksinasi Internasional telah digantikan dengan PMK No. 13 Tahun 2016.

Hasil wawancara yang dilakukan dengan pejabat terkait 


$\begin{array}{lrr}\text { yaitu kepala seksi } & \text { upaya } \\ \text { kesehatan dan lintas } & \text { wilayah } \\ \text { (UKLW) KKP } & \text { Cilacap } \\ \text { disampaikan bahwa } & \text { dasar } \\ \text { hukum bagi } & \text { KKP } & \text { dalam } \\ \text { melaksanakan } & \text { vaksinasi }\end{array}$
meningitis meningokokus bagi jamaah umrah adalah PMK No. 13 tahun 2016. Sebagian besar informan yang merupakan biro penyelenggara umrah juga menjawab pertanyaan peneliti tentang pelaksaan vaksin bagi umrah adalah di KKP hanya saja mereka tidak memahami betul tentang peraturan perundangannya. Ungkapan oleh jamaah umrah juga menambahkan bahwa mengetahui vaksinasi meningitis meningokokus bagi jamaah umrah hanya dilakukan di KKP Kelas II Cilacap bukan tempat lain yang didapatkan dari informasi temannya yang pernah melaksanakan umrah dan juga belum memahami tentang dasar peraturan perundangannya.

Pelayanan vaksinasi meningitis meningokokus merupakan salah satu upaya kesehatan pencegahan dan perlindungan kesehatan yang diwajibkan bagi jamaah umrah dan haji dimana pelaksaannya diberikan kewenangan oleh pemerintah kepada KKP ttermasuk KKP Kelas II Cilacap. Pelayanan vaksinasi meningitis meningokokus di KKP memiliki Standar Operasional Prosedur (SOP) yang telah ditetapkan oleh Direktorat Jenderal Pencegahan dan Pengendalian Penyakit sebagai induk dari KKP.

Alur pelayanan vaksinasi meningitis meningokokus di KKP Cilacap menurut penelitian secara garis besar memang telah sesuai SOP. Standar pelayanan kesehatan yang baik adalah manusia yang memberi pelayanan itu sendiri dalam hal ini tenaga kesehatan dengan kemampuan dan kompetensi yang dimiliki dan sarana prasarana (fasilitas) sesuai dengan SOP yang berlaku di KKP Cilacap dalam pelaksanaan vaksinasi meningitis meningokokus. ${ }^{3}$

Fasilitas pelayanan di KKP II Cilacap ditemukan belum memiliki bentuk fasilitas kesehatan dari Dinas Kesehatan. Hal ini sesuai dengan pernyataan oleh informan-informan dalam penelitian. Fasilitas pelayanan kesehatan merupakan alat atau

3 Philip Kother, 1996, Manajemen Pemasaran Analisis Perencanaan, Implementasi dan Pengendalian, Edisi Keenam Jilid 2, hal 107. Jakarta: Erlangga. 
tempat untuk menyelenggarakan pelayanan kesehatan, baik peningkatan, pencegahan, pengobatan, maupun pemulihan yang dilakukan oleh pemerintah atau masyarakat, termasuk swasta meliputi fasilitas pelayanan kesehatan perorangan dan atau fasilitas pelayanan kesehatan masyarakat yang diselenggarakan oleh Pemerintah (TNI/Polri), Sesuai dengan hasil wawancara, seperti ungkapan oleh Biro Hukum Kementerian Kesehatan menyatakan bahwa Kantor Kesehatan Pelabuhan II Cilacap diselenggarakan di bawah koordinasi Pemerintah Pusat atau Kementerian Kesehatan. Pelaksanaan vaksinasi meningitis meningokokus di KKP II Cilacap oleh tenaga kesehatan (dokter dan perawat) secara administratif memiliki kompetensi sesuai ketentuan berlaku dalam bentuk SIP (surat ijin praktek), namun kenyataan di lapangan, tenaga kesehatan di KKP II Cilacap masih ditemukan ada tenaga kesehatan yang belum memiliki SIP. Pembinaan dan pengawasan oleh Dirjen P2P meskipun sudah ada aturannya, namun masih belum berjalan dengan optimal dalam upaya peningkatan mutu pelayanan kesehatan (kendali mutu dan biaya) dalam pelayanan vaksinasi meningitis meningokokus di Kantor Kesehatan Pelabuhan Kelas II Cilacap.

Berdasarkan penelitian dapat didapatkan bahwa pelaksanaan vaksinasi meningitis meningokokus bagi jamaah umrah di Kantor Kesehatan Pelabuhan Cilacap yang dilakukan oleh tenaga kesehatan yaitu dokter dan perawat terhadap jamaah umrah berdasarkan SOP yang berlaku di KKP II Cilacap meski kekurangannya secara administratif bentuk fasilitas kesehatan KKP sendiri belum jelas dan ada beberapa tenaga kesehatan yang masih belum memiliki SIP, sedangkan pembinaan dan pengawasan oleh Dirjen P2P masih belum berjalan dengan optimal dalam pelaksanaan untuk meningkatkan pelayanan kesehatan vaksinasi meningitis meningokokus bagi jamaah umrah di Kantor Kesehatan Pelabuhan Cilacap.

2. Penerapan Hukum (law enforcement) Kesehatan dalam Penyelenggaraan 


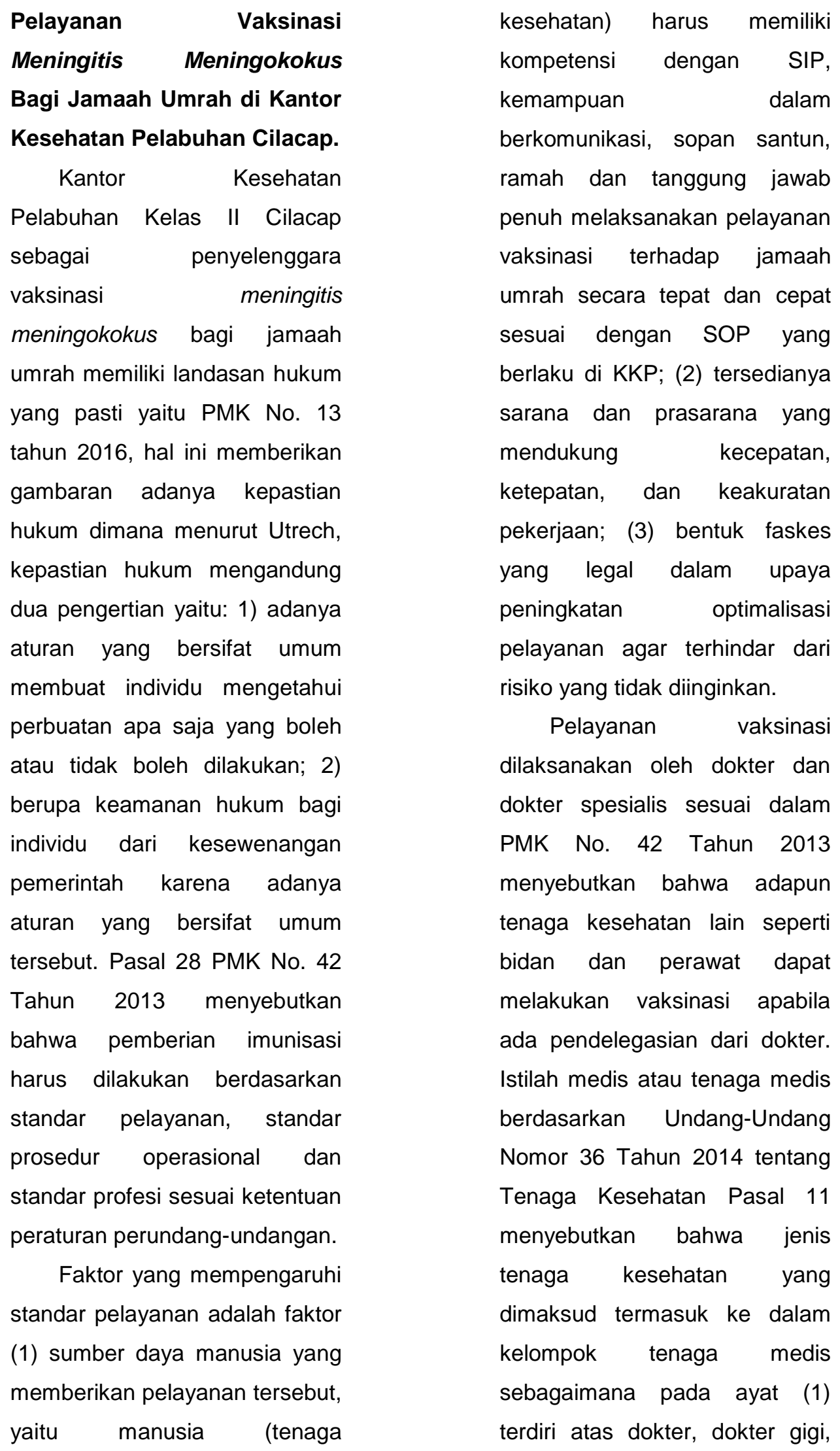


dokter spesialis, dan dokter gigi spesialis. Definisi standar pelayanan, standar profesi dan prosedur operasional beradasarkan Peraturan Menteri Kesehatan Nomor 2052 Tahun 2011 tentang Izin Praktik dan Pelaksanaan Praktik Kedokteran. Pasal 1 Peraturan Menteri Kesehatan Nomor 2052 Tahun 2011 tentang Izin Praktik dan Pelaksanaan Praktik Kedokteran disebutkan bahwa standar pelayanan adalah pedoman yang harus diikuti oleh dokter atau dokter gigi dalam menyelenggarakan praktik kedokteran. Standar profesi adalah batasan kemampuan (knowledge, skill and professional attitude) minimal yang harus dikuasai oleh seorang dokter atau dokter gigi untuk dapat melakukan kegiatan profesionalnya pada masyarakat secara mandiri yang dibuat oleh organisasi profesi. Standar prosedur operasional adalah suatu perangkat instruksi atau langkah-langkah yang dibakukan untuk menyelesaikan suatu proses kerja rutin tertentu yang memberikan langkah yang benar dan terbaik berdasarkan konsensus bersama untuk melaksanakan berbagai kegiatan dan fungsi pelayanan yang dibuat oleh fasilitas pelayanan kesehatan berdasarkan standar profesi.

Berdasarkan penelitian didapatkan bahwa tenaga kesehatan yang ada di KKP Kelas II Cilacap adalah dokter dan perawat. Tenaga kesehatan dokter sdah memiliki SIP sementara tenaga kesehatan perawat belum memiliki SIP. Tenaga kesehatan perawat belum memiliki SIP karena terkendala perijinan dari Dinas Kesehatan Kabupaten Cilacap yang masih menanyakan legalitas tentangbentuk fasilitas kesehatan yang ada di KKP Kelas II Cilacap, sehingga belum dapat menerbitkan SIP pada perawat. Berdasarkan keterangan di atas, didapatkan bahwa legalitas pelayanan vaksinasi meningitis meningokokus di Kantor Kesehatan Pelabuhan Kelas II Cilacap masih menjadi permasalahan, dimana belum semua tenaga kesehatan (perawat dan dokter) yang memiliki surat ijin praktik sebagai syarat mutlak bagi tenaga kesehatan dalam menjalankan kewenangannya.

Berdasarkan penelitian didapatkan bahwa bentuk fasilitas di KKP Kelas II Cilacap masih belum jelas. Permenkes 356 Tahun 2008 hanya menjelaskan tentang tupoksi KKP untuk pelayanan 
kesehatan terbatas dan Permenkes

13 Tahun 2016 hanya menjelaskan tentang pelaksanaan vaksinasi meningitis meningokokus untuk jamaah umrah yang diselenggarakan di KKP Kelas II Cilacap, bukan menjelaskan bentuk fasilitas di KKP Kelas II Cilacap. Peraturan tentang fasilitas pelayanan kesehatan, yaitu Peraturan Pemerintah (PP) No. 47 tahun 2016 tentang Fasilitas Pelayanan Kesehatan.

Belum adanya kepastian dan perlindungan hukum dalam hal ini bentuk fasilitas kesehatan dan SIP perawat yang belum diterbitkan. Hukum akan dapat melindungi hak dan kewajiban setiap individu dalam melaksanakan kualitas pelayanan kesehatan terhadap jamaah umrah. Pembinaan dan pengawasan upaya kesehatan harus diberikan berdasarkan standar pelayanan telah ditetapkan oleh pemerintah dengan memperhatikan masukan dari pemerintah daerah, organisasi profesi atau masyarakat secara berjenjang melalui standarisasi, sertifikasi, lisensi, akreditasi dan penegakan hukum.

$\begin{array}{lr} & \text { Kewajiban pemerintah } \\ \text { dalam penjaminan } & \text { dan } \\ \text { pengawasan mutu pelayanan } & \text { dengan } \\ \text { kesehatan didukung } & \text { dengan } \\ \text { standar pelayanan serta komitmen } & \text { dalam tata pemerintahan yang baik }\end{array}$

(Good Governance). Penerapan konsep pemerintahan yang bijaksana dan penyelenggaraan pemerintahan berdasarkan prinsip "good governance" merupakan prasyarat untuk mendapatkan keseimbangan yang efektif antara lingkungan dan pembangunan. Governance didefinisikan sebagai "pelaksanaan otoritas politik, ekonomi dan administratif dalam pengelolaan sebuah negara, termasuk di dalamnya mekanisme yang kompleks serta proses yang terkait, lembaga-lembaga yang dapat menyuarakan kepentingan baik perorangan atau kelompok masyarakat dalam mendapatkan haknya dan melakukan tanggung jawabnya, serta menyelesaikan perselisihan. Governance berada dalam keadaan yang baik apabila terdapat sinergi antara pemerintah, sektor swasta dan masyarakat sipil dalam pengelolaan sumber alam, sosial, lingkungan dan ekonomi. ${ }^{4}$

Permasalahan perijinan tenaga kesehatan di KKP Kelas II Cilacap dalam ini tenaga perawat, menurut peneliti bisa berpotensi

\footnotetext{
${ }^{4}$ Bambang Rudito, $d k k$, 2005, Meretas Jalan Pemikiran Surya Tjahja Djajaningrat: Dari Sustainable Development Menuju Sustainable Future" dalam Bambang Rudito, dkk (editor), Sustainable Future Menggagas Warisan Peradaban Bagi Anak Cucu Seputar Wacana Pemikiran Surna Tjahja Djajaningrat, Penerbit Indonesia Center for Sustainable Development (ICSD), Jakarta, hlm. 44
} 
menimbulkan permasalahan hukum dimana terkait dengan kepastian hukum dalam standar pelayanan dan juga perlindungan hukum bagi tenaga keperawatan dan pasien sebagai penerima pelayanan kesehatan. Ijin Praktik dalam hal teknisnya berupa Surat ljin Praktik (SIP) adalah bukti tertulis yang diberikan pemerintah kepada tenaga kesehatan professional yang akan menjalankan praktiknya setelah memenuhi persyaratan. ljin menjalankan praktik mempunyai 2 makna, yaitu:

1. Ijin dalam arti pemberian kewenangan secara formil (formeele bevoegdheid)

2. Ijin dalam arti pemberian kewenangan secara materiil (materieele beoegdheid).

Secara teoritis, izin merupakan pembolehan khusus untuk melakukan sesuatu yang secara umum dilarang, sebagai contoh dokter boleh melakukan pemeriksaan bagian tubuh tubuh pasien yang izin tersebut tidak diberikan kepada profesi lain. Izin diberikan dalam bentuk tertulis berdasarkan permohonan tertulis yang diajukan. Lembaga yang berwenang mengeluarkan izin juga didasarkan pada kemampuan untuk melakukan penilaian administrative dan teknis. Instrumen perijinan diatur dalam hukum administrasi negara yang mempunyai hubungan dengan potensi terjadinya perbuatan malpraktek administrasi.

Profesi tenaga pelayan kesehatan berlaku norma etika dan norma hukum, oleh sebab itu apabila timbul dugaan adanya kesalahan praktek sudah seharusnya diukur atau dilihat dari sudut pandang kedua norma tersebut. Kesalahan dari sudut pandang etika disebut ethical malpractice dan dari sudut pandang hukum disebut yuridical malpractice. Malpraktek terkait hukum atau yuridical malpractice dibagi ke dalam tiga kategori sesuai dengan bidang hukum yang dilanggar, yaitu criminal malpractice, civil malpractice dan administrative malpractice.

Criminal malpractice dikategorikan manakala perbuatan tersebut memenuhi delik pidana, yaitu: ${ }^{5}$

1) Perbuatan tersebut (positive act maupun negative act) merupakan perbuatan tercela

2) Dilakukan dengan sikap batin yang salah (mens rea) yang berupa kesengajaan (intensional), kecerobohan

5

https://muhammadjabir.com/2008/10/30/pem buktian-malpraktek-dalam-pelayanankesehatan/, diakses pada tanggal 29 Juli 2018. 
(recklessness) atau kealpaan (negligence).

Criminal malpractice yang bersifat sengaja (intensional) misalnya melakukan euthanasia (pasal $344 \mathrm{KUHP}$ ), membuat surat keterangan palsu (pasal 263 KUHP). Criminal malpractice yang bersifat ceroboh (recklessness) misalnya melakukan tindakan medis tanpa persetujuan pasien. Criminal malpractice yang bersifat negligence (lalai) misalnya kurang hati-hati menyebabkan luka, cacat atau meninggalnya pasien, ketinggalan klem dalam perut pasien saat melakukan operasi. Pertanggungjawaban di depan hukum pada criminal malpractice adalah bersifat individual/personal dan oleh sebab itu tidak dapat dialihkan kepada orang lain atau kepada rumah sakit/fasilitas pelayanan kesehatan.

Civil malpractice dikategorikan apabila tenaga kesehatan tidak melaksanakan kewajiban atau tidak memberikan prestasinya sebagaimana yang telah disepakati atau ingkar janji. Tindakan tenaga kesehatan yang dapat dikategorikan sebagai civil malpractice antara lain:

1) Tidak melakukan apa yang menurut kesepakatannya wajib dilakukan.
2) Melakukan apa yang menurut kesepakatannya wajib dilakukan tetapi terlambat melakukannya.

3) Melakukan apa yang menurut kesepakatan wajib dilakukan tetapi tidak sempurna.

4) Melakukan apa yang menurut kesepakatannya tidak seharusnya dilakukan.

Pertanggungjawaban hukum pada civil malpractice dapat bersifat individual atau korporasi dan dapat pula dialihkan kepada pihak lain berdasarkan principle of vicarius liability dimana rumah sakit atau fasilitas pelayanan kesehatan dapat bertanggung jawab atas kesalahan yang dilakukan karyawannya (tenaga kesehatan)

Administrative malpractice dikategorikan ketika tenaga kesehatan telah melanggar hukum administrasi, dimana kententuanketentuan perundangan di bidang kesehatan telah ditetapkan oleh pemerintah. Malpraktek administrasi (administrative malpractice) adalah apabila tenaga kesehatan telah melanggar hukum administrasi. Pelanggaran terhadap hukum administrasi tersebut antara lain seperti dokter tidak mempunyai Surat ljin Praktik (SIP), perawat tidak mempunyai SIP atau melanggar batas kewenangan tenaga keperawatan. Secara umum 
maladministrasi diartikan sebagai perilaku atau perbuatan melawan hukum dan etika dalam suatu proses administrasi pelayanan publik,yakni meliputi penyalahgunaan wewenang/jabatan, kelalaian dalam tindakandan pengambilan keputusan, pengabaian kewajiban hukum, melakukanpenundaan berlarut, tindakan diskriminatif, permintaan imbalan, dan lainlainyang dapat dinilai sekualitas dengan kesalahan tersebut. Dalam hukum positif Indonesia ada 9 kriteria yang menjadi kategori maladministrasi yaitu; (1) Perilaku dan perbuatan melawan hukum (2) Perilaku dan perbuatan melampaui wewenang,

Menggunakan wewenang untuk tujuan lain dari yang menjadi tujuan wewenang tersebut, (4) Kelalaian (5) Pengabaian kewajiban hukum (6) Dalam penyelenggaraan pelayanan publik (7) Dilakukan oleh Penyelenggara Negara dan pemerintahan (8) Menimbulkan kerugian materiil dan/atau immaterial (9) Bagi masyarakat dan orang perseorangan. ${ }^{6}$

Definisi maladministrasi menurut Undang-Undang Nomor 37 Tahun 2008 tentang Ombudsman RI pasal

http://www.academia.edu/9378268/MEMA HAMI_MALADMINISTRASI, diakses pada 30 Juli 2018.
1 adalah perilaku atau perbuatan melawan hukum, melampaui wewenang, menggunakan wewenang untuk tujuan lain dari yang menjadi wewenang tersebut, termasuk kelalaian atau pengabaian kewajiban hukum dalam penyelenggaraan pelayanan publik yang dilakukan oleh penyelenggara negara dan pemerintahan, termasuk perseorangan yang membantu pemerintah memberikan pelayanan publik yang menimbulkan kerugian materiil dan/atau imateriil bagi masyarakat dan orang perseorangan.

Berdasarkan ketentuan Undang-undang Nomor 25 Tahun 2009 tentang Pelayanan Publik, masyarakat yang menjadi korban maladministrasi dapat menggugat penyelenggara pelayanan publik atau pelaksana pelayanan publik melalui peradilan tata usaha negara apabila pelayanan yang diberikan menimbulkan kerugian di bidang tata usaha negara, masyarakat dapat menggugat perdata apabila penyelenggara pelayanan publik atau pelaksana pelayanan publik melakukan perbuatan melawan hukum secara perdata. Masyarakat juga dapat melaporkan/menuntut secara pidana kepada kepolisian ketika penyelenggara pelayanan publik 
atau pelaksana pelayanan publik diduga melakukan tindak pidana, dimana proses ini tidak menghapus kewajiban pelaku maladministrasi untuk melaksanakan keputusan Ombudsman dan/atau atasan pejabat pelaku maladministrasi.

Sanksi pada maladministrasi umumnya berupa teguran lisan, tertulis dan pencabutan izin. Ombudsman dapat merekomendasikan sanksi yang berupa sanksi administrasi yaitu sanksi teguran tertulis, sanksi pembebasan dari jabatan,sanksi penurunan gaji sebesar satu kali kenaikan gaji berkala untuk paling lama1 (satu) tahun, sanksi penurunan pangkat pada pangkat yang setingkat lebihrendah untuk paling lama 1 (satu) tahun, sanksi pemberhentian dengan hormat tidak atas permintaan sendiri, sanksi pemberhentian tidak dengan hormat,sanksi pembekuan misi dan/atau izin yang diterbitkan oleh instansi pemerintah,sanksi pencabutan izin yang diterbitkan oleh instansi pemerintah. Selain itu,Ombudsman hanya menyarankan penjatuhan sanksi pidana sesuai peraturan perundang-undangan yang berlaku, sanksi membayar ganti rugi dan pengenaan denda yang ditetapkan berdasarkan putusan pengadilan yang merupakan ranah hukum perdata.

Belum adanya kepastian dan perlindungan hukum dalam hal ini bentuk fasilitas kesehatan dan SIP perawat yang belum diterbitkan. Hukum akan dapat melindungi hak dan kewajiban setiap individu dalam melaksanakan kualitas pelayanan kesehatan terhadap jamaah umrah. Pembinaan dan pengawasan upaya kesehatan harus diberikan berdasarkan standar pelayanan telah ditetapkan oleh pemerintah dengan memperhatikan masukan dari pemerintah daerah, organisasi profesi atau masyarakat secara berjenjang melalui standarisasi, sertifikasi, lisensi, akreditasi dan penegakan hukum.

Berdasarkan wawancara dan analisis yang telah dilakukan maka diperoleh dalam hal prinsip-prinsip good governance pelaksanaan vaksinasi meningitis mengikokus di KKP II Cilacap meliputi :

1. Prinsip transparasi dengan memastikan pelayanan vaksinasi terhadap jamaah umrah sesuai dengan fasilitas yang didapatkan maka akan mendapat kepercayaan dari banyak jamaah, hanya masih belum adanya transparasi bentuk fasilitas kesehatan dalam pelaksanaan vaksinasi meningitis pada jamaah umrah 
di KKP II Cilacap oleh Dinas

Kesehatan.

2. Penegakan hukum yang diterapkan belum dipatuhi oleh tenaga medis dan bentuk fasilitas kesehatan di KKP II Cilacap itu sendiri. Seyogyanya tenaga medis dan bentuk fasilitas kesehatan dilindungi hukum, karena penyelenggaara haji dan umrah resmi itu diatur atau tunduk terhadap aturan yang ada, misalnya tenaga medis belum memiliki SIP tentunya membuka celah permasalahan hukum apabila ternyata di ketahui oleh pihak yang paham tentang hukum kesehatan dan juga apabila nantiknya terjadi sengketa hukum akibat permasalahan dalam pelayanan kesehatan yang sering dikenal di masyarakat sebagai malpraktik. Fasilitas kesehatan yang ada di KKP Cilacap ternyata belum memiliki bentuk yang jelas peraturan perundangannya sehingga dapat dipertanyakan tentang kualitas pelayanan yang diberikan karena untuk fasilitas-fasilitas pelayana kesehatan yang lain seperti Puskesmas, Klinik, Rumah Sakit dan praktik pribadi tenaga kesehatan telah memiliki peraturan yang jelas. Kondisi ini apabila terjadi pada fasilitas pelayanan yang diselenggarakan oleh masyarakat mungkin bisa menjadikan permasalahan tersendiri. Permasalahan yang sudah jelas terjadi adalah adanya pertanyaan dari Dinas Kesehatan Kabupaten Cilacap tentang bentuk fasilitas kesehatan di KKP yang diteruskan dalam tidak bisa diterbitkannya Surat Ijin Kerja Perawat (SIKP) di KKP Cilacap.

3. Prosedur dan kualitas penyelenggaraan vaksinasi meningitis mengokokus di KKP II Cilacap dalam pelayanan kepada masyarakat sudah baik dengan menyetarakan pelayanan kesehatan setiap jamaah umrah semua sama.

4. Bentuk partisipasi yang dilakukan pihak penyelenggara vaksinasi terhadap jamaah umrah dalam bentuk tanggung jawab belum jelas dalam hal memenuhi standar pelaayanan yaitu bentuk fasilitas pelayanan dan ijin pelayanan pada tenaga kesehatan yang terlibat.

5. Akuntabilitas memberikan pelayanan yang maksimal dan 
bertanggung jawab sudah berjalan dengan baik.

6. Bentuk efektivitas dan efisiensi dengan bersikap profesional dalam pelayanan sudah baik namun belum profesional secara hukum karena beberapa tidak memiliki SIP pada tenaga perawat.

\section{SIMPULAN DAN SARAN}

\section{Simpulan}

Berdasarkan pada hasil penelitian dan pembahasan dapat diambil kesimpulan sebagai berikut :

a. Pelaksanaan pelayanan vaksinasi meningitis meningokokus bagi jamaah umrah di Kantor Kesehatan Pelabuhan Kelas II Cilacap sudah sesuai dengan standar pelayanan kesehatan dengan menjalankan SOP yang berlaku di Kantor Kesehatan Pelabuhan Kelas II Cilacap dimana SOP yang ada merupakan SOP yang ditentukan oleh Kementerian Kesehatan Republik Indonesia dalam hal ini adalah Direktorat Jenderal Pencegahan dan Pengendalian Penyakit yang menjadi induk dari KKP. Jamaah umrah sebagai konsumen atau masyarakat kesehatan yang menggunakan pelayanan di KKP Cilacap dalam melaksanakan vaksinasi meningitis meningokokus sebagai persyaratan wajib dalam pengurusan visa menuju Arab Saudi secara umum menyatakan bahwa pelayanan di KKP Cilacap sudah baik.

b. Penerapan hukum dalam pelaksanaan vaksinasi meningitis meningokokus bagi jamaah umrah di Kantor Kesehatan Pelabuhan Kelas II Cilacap masih terdapat permasalahan karena belum mengikuti peraturan sesuai dengan standar pelayanan yaitu dalm hal bentuk fasilitas kesehatan di KKP Cilacap yang belum memiliki aturan yang baku dan Surat Ijin Praktik dari tenaga kesehatan yang ada di KKP Cilacap. Setiap fasilitas pelayana kesehatan harus memiliki dasar hukum yang jelas agar dapat menjalankan peran dan fungsinya dengan maksimal dan legal dan untuk KKP secara umum termasuk KKP Cilacap sampai saat ini belum didapatkan paraturan perundangan yang khusus 
mengatur tentang bentuk fasilitas kesehatan di KKP, hal ini menjadikan permasalahan ketika Dinas Kesehatan Kabupaten Cilacap tidak bisa mengeluarkan Surat ljin Kerja Perawat (SIKP) dikarenakan belum adanya kejelasan tentang bentuk fasilitas kesehatan di KKP. Bagi tenaga medis Surat Ijin Praktik tetap bisa diproses oleh Dinas Kesehatatan setempat karena bagi tenaga medis yang ada di KKP Cilacap digolongkan sebagai praktik pribadi dengan alamat praktik di KKP Cilacap. Surat ljin Praktik merupakan ijin legal formal bagi setiap tenaga kesehatan dalam menjalankan kompetensi dan kewenangannya sehingga apabila surat ijin tidak ada, secara hukum maka tenaga kesehatan tersebut tidak diperbolehkan melakukan apa yang menjadi kompetensi dan kewenangannya.

\section{Saran}

Saran-saran yang dapat dibuat berdasarkan hasil penelitian dan pembahasan sebagai berikut : a. Perlu segera dikeluarkan peraturan perundangan tentang bentuk atau jenis fasilitas kesehatan di Kantor Kesehatan Pelabuhan.

b. Pemantauan dan pembinaan yang lebih jelas dan tegas terhadap KKP dalam pelaksanaan pelayanan vaksinasi meningitis meningitis bagi jamaah umrah yang menjadi salah satu tugas dan fungsi KKP termasuk KKP Cilacap. Pemantauan dan pembinaan ini akan memaksimalkan upaya pemerintah dalam pemberian pelayanan kesehatan yang berkualitas termasuk di dalamnya pelaksanaan peraturanperaturan secara harmonis sebagai perwujudan good governance.

c. Perlu penelitian lebih lanjut tentang kesadaran hukum dari tenaga kesehatan maupun pimpinan fasilitas kesehatan di Kantor Kesehatan Pelabuhan Cilacap tentang hukum kesehatan yang ada.

\section{DAFTAR PUSTAKA}

Azra, Azyumardi, 2005, Demokrasi, Hak Asasi Manusia, Masyarakat Madani, Jakarta, Prenada Media 
Direktorat Jenderal Pemberantasan Penyakit Menular dan Penyehatan Lingkungan Pemukiman, 1994, Meningitis Meningokokus; Buku Pedoman Bagi Jamaah Haji Indonesia, Departemen Kesehatan RI Direktorat Jenderal Pemberantasan Penyakit Menular dan Penyehatan Lingkungan Pemukiman, Jakarta.

Direktorat Jenderal Penyelenggaraan Haji, 2013, Modul; Bimbingan Manasik Haji, Umrah dan Ziarah Bagi Petugas Haji; Bahan Ajar Pelatihan Petugas Haji tahun $1434 \mathrm{H} / 2013 \mathrm{M}$, Kementerian Agama RI Direktorat Jenderal Penyelenggaraan Haji dan Umrah, Jakarta.

Djauzi, Samsuridjal, Iris Rengganis, Sukamto Koesnoe, Ardhi Rahman Ahani, 2012, Pedoman Imunisasi Pada Orang Dewasa, Balai Penerbit FKUI, Jakarta.

Fajar, Mukti ND, Dkk, 2010, Dualisme Penelitian Hukum Normatif dan Empiris. Pustaka Pelajar. Yogyakarta.

HR, Ridwan, 2007, Hukum Administrasi Negara, PT Raja Graffindo Persada, Jakarta

Mertokusumo, Sudikno, 1996, Mengenal Hukum, Liberty, Yogyakarta.

Miles, Mathew B dan A. Michael Huberman, 1992, Analisis Data Kualitatif:Buku Sumber tentang Metode-Metode

Baru, Penerjemah: Tjejep Rohendi Rohidi, Universitas Indonesia (UI Press), Jakarta.

Moleong, L.J, 2010, Metodologi Penelitan Kualitatif, Cetakan XXVIII. Remaja Rosdakarya, Bandung.

Rahardjo, Satjipto, 2014. Ilmu Hukum, Cetakan VIII, Citra Aditya Bhakti, Bandung.

Soemitro, Ronny Hanitijo, 1990, Metodologi Penelitian dan Jurimetri Cet.4, Ghalia Indonesia, Jakarta.

Soekanto, Soerjono 1982, Kesadaran Hukum dan Kepatuhan Hukum, Jakarta, CV.Rajawali.
Soekanto, Soerjono, 1985, Penelitian Hukum Normatif Suatu Tinjauan Singkat, Jakarta, CV Rajawali.

Soekanto, Soerjono, 2007, Penelitian Hukum Normatif, Jakarta, Raja Grafindo Persada.

Soekanto, Soerjono, 2010, Pengantar Penelitian Hukum, Jakarta, UIPress.

Sugiyono, 2008, Metode Penelitian Kuantitatif Kualitatif dan $R \& D$, Bandung, Alfabeta Asas Kepastian Hukum, http://tesishukum.com/pengertianasas-kepastian-hukum-menurutpara-ahli. diakses 22 Desember 2015 